\title{
A Typology of Institutional Frameworks for Organizations
}

\author{
Marcel Van Marrewijk \\ Van Linden van den Heuvellsingel 7, Vlaardingen, Netherlands \\ E-mail:marcel@vanmarrewijk.nl \\ Received October 26, 2009; revised December 24, 2009; accepted December 25, 2009
}

\begin{abstract}
Inspired by Dr. Clare Graves' research on evolutionary developments in value systems and levels of existence, this paper introduces an integral business framework - a sequence of ideal type organizations - each characterized by specific institutional arrangements. A table-the transition matrix - summarizes the specific features of each type. It is an update of former version based upon an international EU-financed ECSF research project [1].
\end{abstract}

Keywords: Value Systems, Organization Types, Responsive Scorecard, Organization Framework, Order, Success, Community, Synergy, Spiral Dynamics

\section{Introduction}

With Spiral Dynamics, based on the research of Clare Graves [2], summarized in paragraph two, this paper presents ideal type organizations structured according the Gravesian holarchy of value systems. Each type is showing a coherent set of ambitions, relating institutional structures and corresponding business practices, demonstrating different levels of corporate performance and manifestations of for instance sustainability.

In the final paragraph the author presents the Transition Matrix, published earlier in the Journal of Business Ethics [3]. It was the first step in a development that created a more sophisticated integral management framework - coined the Cubrix [4], introduced in the previous edition of this journal.

\section{Value Systems}

\subsection{Graves’ Value Systems Model}

In the 1950s through 1970s Professor Clare W. Graves performed extensive empirical research regarding values and levels of existence (value systems). The focus of his research - how does the mind process reality - resulted in a overall framework for "healthy adult behavior" which he coined the "Emergent, Cyclical, Double-Helix Model of Adult BioPsychoSocial Systems Development”. He rarely published his findings. In 1996, his successors, Don Beck and Chris Cowan, introduced Graves' Emerging Cyclical Level of Existence Theory-the shorter title of his model—as Spiral Dynamics [2].

Based on Graves' research they concluded that mankind has gradually developed eight core value systems so far. A value system is a way of conceptualizing reality and encompasses a consistent set of values, beliefs and corresponding behavior and can be found in individual persons, as well as in companies and societies.

The development of value systems occurs in a fixed order. These can be tagged as follows: Survival; Security; Energy and Power; Order; Success; Community, Synergy and Holistic life system. Each new value system includes and transcends the previous ones, thus forming a natural hierarchy (or holarchy).

In most occasions, a value system develops in reaction to specific environmental challenges and threats: the systems brighten or dim when life conditions (consisting of historic Times, geographic Place, existential Problems and societal Circumstances) change. Transformations, that is shifts of contexts, actually occurs when life conditions (LC) have build up a sufficient level of urgency among entities to leave behind their proven patterns of behavior. Secondly, these entities must have a supportive mind capacity (MC) to be able to match the new challenges life conditions offer and generate new adequate behavior and subsequent institutional arrangements.

It is all about balancing MC and LC. Psychologically, people might not be able to match changes in the environment, so they remain "arrested" towards future needs or even "closed" to less complex value systems that, naturally - should have been included in their repertoire.

Entities such as people and organizations will eventually have to meet the challenges their situation provides 
or risk the danger of oblivion or even extinction. If for instance societal circumstances change, inviting corporations to respond and consequently reconsider their role within society, it implies that corporations have to realign their value systems and all their business institutions (such as mission, vision, policy deployment, decision-making, reporting, corporate affairs, etcetera) to these new circumstances.

The quest to create an adequate response to specific life conditions results in a wide variety of survival strategies, each founded on a specific set of value assumptions and demonstrated in related institutions and behavior.

Out of the eight core Gravesian value systems, we are only taking the six most recent ones as these are most relevant in the context of corporate sustainability. The same color codes as introduced by Beck and Cowan [2] are used to label the value systems, respectively red, blue, orange, green, yellow and turquoise. In Table 1 a short description of each value system is given, in relation to (the perceptions of) the environment (life conditions), which induce the value system.

\section{Organization Types}

\subsection{Thinking Systems}

It is absolutely essential to understand that Gravesian value systems are distinguishing types of thinking in people and not types of people. It is about the intentions and awareness of people and their actual thinking systems to match the issue at hand. A person is not "Blue". No, a Blue way of thinking is dominant within this person.

When the coping possibilities a value system offers are no longer sufficient to provide an appropriate response to the existing circumstances, there is an incentive to move on to the next value system. The awareness that a current pattern of behavior or a certain institution is no longer adequate to tackle a problem can propel a change in the perception of reality. Increasing complexity requires more complexity of the value systems in coping with the situation. More complex value systems allow more degrees of freedom to act in accordance with the environment.

The question is often posed: "Is a more complex value system better than a basic one? In general, the answer is no. When the life conditions are adequately dealt with in less complex value system there is no need to aim for a higher value system. However, in highly complex environments, Yellow can provide a more adequate response to outside challenges than Blue because it offers more degrees of freedom to act appropriately under varied circumstances. The real issue therefore is "adequateness", the ability to provide a balance between Life Conditions and Mind Capacity.

The gradual move to a new value system facilitates new patterns of behavior and the creation of new institutions in line with the emerging value system. In other words, challenged by changing circumstances and provoked by new opportunities, individuals, organizations and societies develop adequate solutions, creating synergy and adding value at a higher level of complexity. Since instability increases at higher complexity levels,

Tabel 1. Development of human and organizational value systems, inspired by Graves and Spiral Dynamics [2].

\begin{tabular}{|c|c|c|c|c|c|c|}
\hline $\begin{array}{l}\text { Main Themes- } \\
\text { Labels }\end{array}$ & $\begin{array}{l}\text { Energy \& Power } \\
\text { (Red) }\end{array}$ & $\begin{array}{l}\text { Order } \\
\text { (Blue) }\end{array}$ & $\begin{array}{l}\text { Success } \\
\text { (Orange) }\end{array}$ & $\begin{array}{l}\text { Community } \\
\text { (Green) }\end{array}$ & $\begin{array}{l}\text { Synergy } \\
\text { (Yellow) }\end{array}$ & $\begin{array}{c}\text { Holistic life } \\
\text { System } \\
\text { (Turquoise) }\end{array}$ \\
\hline $\begin{array}{l}\text { Environment: } \\
\text { Life Conditions }\end{array}$ & $\begin{array}{l}\text { Limitless challenges } \\
\text { about boundaries of } \\
\text { the territory and to } \\
\text { be dominant over } \\
\text { self and others } \\
\text { within the territory. }\end{array}$ & $\begin{array}{l}\text { Ordered } \\
\text { relationships } \\
\text { requiring } \\
\text { legitimization in } \\
\text { order to ensure } \\
\text { stability and } \\
\text { security for the } \\
\text { future }\end{array}$ & $\begin{array}{l}\text { Many viable } \\
\text { alternatives for } \\
\text { progress, prosperity } \\
\text { and material gain } \\
\text { since change is the } \\
\text { nature of things }\end{array}$ & $\begin{array}{l}\text { The gap between } \\
\text { people and their } \\
\text { (material) } \\
\text { Possibilities } \\
\text { has become } \\
\text { disproportionately } \\
\text { large }\end{array}$ & $\begin{array}{l}\text { Complex problems } \\
\text { that cannot be solved } \\
\text { within the current } \\
\text { systems as awareness } \\
\text { of broad } \\
\text { interconnections } \\
\text { grows. }\end{array}$ & $\begin{array}{l}\text { The consequences } \\
\text { of human actions } \\
\text { threaten the } \\
\text { planet's living } \\
\text { systems and } \\
\text { demand } \\
\text { coordinated effort. }\end{array}$ \\
\hline Life Force & $\begin{array}{l}\text { Conquering } \\
\text { Domination }\end{array}$ & Belief & $\begin{array}{l}\text { Achievement } \\
\text { Changeability }\end{array}$ & Belonging & Understanding & Interconnections \\
\hline Main Focus & Individual/self & Group/collective & Individual/self & Group/collective & Individual/self & Group/collective \\
\hline $\begin{array}{l}\text { Thinking System: } \\
\text { Mind Capacity }\end{array}$ & Egocentric/cunning & $\begin{array}{l}\text { Absolutistic/linear } \\
\text { (consequential) }\end{array}$ & $\begin{array}{l}\text { Multiplistic/ } \\
\text { calculating }\end{array}$ & $\begin{array}{l}\text { Sociocentric/ } \\
\text { affiliative }\end{array}$ & Systemic/existential & $\begin{array}{l}\text { Holistic/ } \\
\text { experimental }\end{array}$ \\
\hline Typical Values & $\begin{array}{l}\text { Courage, vitality, } \\
\text { strength, respect, } \\
\text { personal power, } \\
\text { rivalry, territorial, } \\
\text { intimidation, } \\
\text { hedonism, loyalty to } \\
\text { persons }\end{array}$ & $\begin{array}{l}\text { Clarity, discipline, } \\
\text { one truth, loyalty, } \\
\text { duty, guilt, justice, } \\
\text { conformity, obedi- } \\
\text { ence, orderliness, } \\
\text { quality, craft- } \\
\text { man-ship }\end{array}$ & $\begin{array}{l}\text { Results, reward, } \\
\text { entrepreneurial, } \\
\text { image, career } \\
\text { advancement, } \\
\text { productivity, guts, } \\
\text { creativity, control, } \\
\text { satisfaction }\end{array}$ & $\begin{array}{l}\text { Consensus, conflict } \\
\text { avoidance, team-work, } \\
\text { equality, participation, } \\
\text { honesty and open- } \\
\text { ness, being a decent } \\
\text { person, harmony }\end{array}$ & $\begin{array}{l}\text { Insight, integrity, } \\
\text { learning, long-term } \\
\text { orientation, ability to } \\
\text { reflect, flexibility, } \\
\text { tolerance for } \\
\text { uncertainty and } \\
\text { paradoxes }\end{array}$ & $\begin{array}{l}\text { Inspiration, } \\
\text { interdependence, } \\
\text { future generations, } \\
\text { ability to forgive, } \\
\text { wisdom, } \\
\text { sufficiency, } \\
\text { responsible living }\end{array}$ \\
\hline
\end{tabular}


entities can shift to lower levels if circumstances turn unfavorable or if competences fail to meet the required specifications. Charles Darwin once concluded: "It is not the strongest of the species that survive, nor the most intelligent, but the one most responsive to change”.

When one studies particular expressions (e.g. certain behavior) within an organization one should not deduct automatically that the related value system is functioning. Since a particular value system includes and transcends previous ones, a basic expression can be found in all contexts. For example rules and regulations will be found in every organization, not only in organizations with a dominant Blue value system. The key question when certain behavior is displayed is: "Why is it important for you to do this?” In the example of rules and regulations, in the case of a Blue value system, the answer to this question could be: "Because rules provide me with the desired order and stability; rules are important by themselves and must be followed”. In an Orange value system the answer might be: "Because the rules we use ensure smooth functioning and lead to success and high profit; rules can be followed as long as they help us in achieving our goals (and can be bent when not)".

In presenting ideal type organizations we will focus on the institutional structures and arrangements of four core value systems, for which we use the color codes, introduced by Christopher Cowan, the co-author of Spiral Dynamics. The selected systems are Order, Success, Community and Synergy, i.e. blue, orange, green and yellow. The transition zones between core value systems are also not included in the analyses. Each context is introduced by the underlying value system, its dominant worldview and related, often psychological explanations, which brings forth supporting institutional arrangements and structures.

\subsection{Compliance-Driven, Based on Order (Absolute Order: Blue)}

Introduction of the value system

Before mankind experienced Order, it was able to function at three previous levels of existence characterized by the Survival, Security (bonding order) and 'Energy and Power (powerful self)'. Historically, loose tribes evolved to clans, seeking refuge in kinships, rituals, holy ancestors and mystical nature. The value system supporting Security can also be observed in the mother and child relationship, in feelings of pride and belonging and in the identity of organizations. Its color code is Purple.

Freeing themselves from kinships and family ties, people gradually experienced ways of expressing themselves guiltlessly and selfishly, so as to find immediate pleasure and avoid shame in a world of domination, threats and ego. Power and Energy - indicated with Red - can be easily recognized in feudal states, in perseverance when the going gets tough and in negative manifestations such as in traffic (road rage), hooliganism and "party animals". Red lacks the capacity for long-term sequential thinking. They feel no guilt, only the need to gratify impulses and senses immediately. Individual persons tend to manifest these energies especially when they are young (set limits and they will test it!) or in adverse times (CEOs, admirals). These manifestations relate to an environment with limited possibilities, with a shortage of sources, provoking entities to fight in order to gain control and get their share.

When people learn to transcend the self, experience consequential thinking, they are able to live up to "higher ideals", find pride and fulfillment in their work and accept sacrifices now so as to obtain rewards later. New values emerged that matched a quest for order, meaning and purpose. History has shown empires transcending the feudal states. Christianity, communism, armies and bureaucracies represented absolute order, providing a master plan that puts people in their proper places. Impulses are controlled through discipline, guilt and punishments. The rightful authorities seek order and stability and succeed in making their people believe to sacrifice themselves for future rewards.

People "with a lot of blue" live by the book. They try to comply with the laws, regulations, procedures and agenda's that structure their lives. Life is relatively simple: for each problem there is a proven practice and a guidebook to help them solving it, step by step.

Organizational features associated with Order

Organizations grounded in Order have a clear purpose, often explicitly or implicitly founded on principles, which often find their background in history and religion. Organization-wide there is a strong sense of moral duty.

These organizations are structured in strict bureaucracies, with the status of each individual linked to its position in the hierarchy. The archetype leadership style is "manager": formulating top-down planning schemes and policy deployment, determining control systems and budgets and designing and maintaining procedures and a clear division of tasks.

Taylorism is an approach typically linked to Order. Taylor's principles of standardization, specialization, maximization, concentration and centralization are typical features according to which business is run. Furthermore, the Deming's Quality Circle and other traditional quality tools as well as optimizing techniques and resource allocation are applied in order to economize on costs and expenditures.

Focusing on the various departments within an organization, one can observe that the production system is based on internal priorities and mainly technology-oriented in order to create economies of scale and vertical integration. They often dominate or try to include the supply chain within the hierarchy. Innovations are often of incremental nature and mainly apply to product development. 
The people department is mainly an administrative unit, with employees fulfilling their tasks provided by line managers. Corporate behavior can often be characterized as authoritarian and custodial ${ }^{1}$. The market strategy is primarily a supply push approach, charging consumers a price based on integral costs plus a justifiable margin.

It is a goal-oriented system, with a focus on assigned tasks, not on persons.

Progress in Order is measured in terms of material wealth. The traditional scorecard format, relating to Order, is the annual financial report organizations have to show to Tax Authorities, the Chamber of Commerce or the Stock Exchange, in case the organization is publicly listed. The format is determined by law and carefully described by accountancy boards, such as the ACCA.

Organizations in Order expect governments to provide clear legislation and subsequent enforcement, which is effective and visible (law and order). Business' role in society is more or less independent and social welfare is the exclusive responsibility of the state.

The "license to operate" is applicable to organizations that are compliance-driven, thus matching Order.

Certain things are best done in the "blue way", such as maintenance, bookkeeping, chemistry, refineries, energy production and transport. The banking system, court's practices, the judge and jury, are all embedded in Absolute Order. Also private companies rely on a basic blue fundament: "a deal is a deal". Contracts are important ways to conclude arrangements between people and organizations.

Furthermore, many public services flourish within a hierarchical environment, but fail once these services are privatized and left to compete within a market environment.

With too much emphasis on linear thinking and values such as discipline, one truth, loyalty, duty, guilt, conformity, justice, obedience and orderliness the blue way attracts adverse effects such as:

- Limited problem solving capacity and reluctant creativity;

- Suffocating rules and procedures for employees and customers;

- Planning and regulation is more important than the objective;

- One truth, one right way, always categorical.

These omissions created the seeds for a new value system to emerge. It awaited the right circumstances to change paradigms once more. Instead of being what you are meant to be, more and more people longed to be who they could become. What kind of organization supports this new attitude?

${ }^{1}$ Davis (1967): Authoritarian refers to the authority of the CEO (or minister), and the custodial (paternalistic) on the organization as a whole securing the (basic) needs of the employees. [5]

\subsection{Profit-Driven Based on Success and Entrepreneurship (the Enterprising Self: Orange)}

\section{Introduction of the Value System}

In a world with plenty of viable alternatives for progress, prosperity and material gain, people and organizations with a sufficient level of Orange realize that change is in the nature of things and (personal) success within reach of anyone with talents and guts. When you are born a "dime" the "Enterprising Self" knows how to grow into something larger and gain control over its destiny. Success is the new name of the game in an environment offering plenty opportunities to compete, win and make things better and better.

In Success multiplistic thinking evolved offering many options and choices. In Order, people compared to the standard, but here they benchmark themselves against competition and the number one. People with a lot of Orange recognize change is the nature of things, creating new niches and introducing new technologies, enhancing life for many.

They work hard - preferably make others work hard for them - and risk time and money (not their life, as in Red) to achieve prosperity and material gain. They seek out the "good life" and abundance, rather than rewards hereafter. The expression "keep up with the Joneses" is typically Orange. Both people and organizations act in a calculated way while striving for autonomy and independence, seeking for progress and success with the best solutions. If they are allowed to, they try to master nature and exploit its resources.

Organizational features associated with Success and Entrepreneurship

Organizations with a dominant level of Orange make use of an active hierarchy, with informal and pragmatic lines of communication. The matrix and business unit structure are Orange varieties to open up and loosen the hierarchies, while maintaining a firm grip on business processes.

Through typically Orange values such as image, productivity, creativity, career advancement, entrepreneurship and control companies are result-oriented through (gradual and continuous) improvement, stimulating a desire to compete and to become better.

The archetype role of leaders is the Entrepreneur: discovering niches as opportunities for success, putting together new "combinations", creating the necessary means and enjoying the fruit of their labor. Burton Klein's "Happy Warrior" and Schumpeter's "perennial gale of creative destruction" are classic illustrations of the entrepreneurial drive behind capitalism.

Success in this context is primarily measured in terms of money and commercial assets. Organizations, having already established a sound-Blue-production system tend to focus on marketing efforts in trying to gain market 
share. Related practices such as communication, and advertising are also important activities in Success, with often pretending and "make believe" as its underlying intentions. "Window dressing" is invented in Orange!

Organizations engage with suppliers in a market environment, with contracts primarily based on prices and secondly, on specific quality requirements. Product development takes place, especially diversification, moreover Orange gained the competences to enhance process innovations and apply them in the context of quality management.

Human Resource Management treats employees as full time equivalents, as resources, and as costs, carefully selecting where each employee fits best. Employee satisfaction is the crucial standard for HR-performance measurement. HR managers might support its employees with bonuses, various benefits, training facilities and alike, when they are convinced it will lead to higher revenues, lower (turnover) costs and corporate success. In the same way, CS/CSR is accepted only as an opportunity to gain success, significantly reduce risks or enhance reputation, image, prestige and personal esteem. Thus, companies tend to embrace CS/CSR, the moment CS/CSR activities are supported with business case evidence.

A commonly applied measuring format, typically matching Success and Entrepreneurship, is the Business Balanced Scorecard, introduced by Kaplan and Norton. Its anchor point remains the financial position of the organization, but it also identifies three contributory elements: customers, people and processes and corporate lea- rning. See Figure 1.

Organizations expect governments to abstain from over-regulating their markets, as these are jeopardizing their profits and interfere with their sense of freedom. Governments should create and maintain "level playing fields" and allowing companies a "license to grow". According to Orange norms, the voluntary character of corporate sustainability and responsibility particularly must never be violated.

Activities best done in Success are entrepreneurship and marketing, sales and promotion activities in order to boost the commercial capacity of the organization.

People with a lot of Orange tend to be pragmatic. This attitude gives rise to ethical issues since the end is more important than the means. With profits gained at the expense of the weaker, the Entrepreneurial system generates dropouts. Tending to elitism, Orange is inattentive to a fair distribution. With a hang to quantity and profits instead of quality and durability, Success creates "consumerism" and a huge waste stream. Moreover striving for success often becomes compulsive, leaving orangists no time to enjoy their fruits.

The spillover of the entrepreneurial successes gave rise to a new value system, shortly introduced in the next section.

\subsection{Care-Driven, Based on Community (the Egalitarian Order: Green)}

Introduction of the Value System

The Purple reciprocity and Orange accumulation of material wealth paved the way for Green redistribution of society's resources among all. The self is once more being sacrificed, but this time in a world where compassion and belonging are paramount, where everything is relative and "truth" is a matter of context and the group's needs. Community liberates humans from dogma and greed, promoting a sense of community and unity. Solidarity is felt with the weaker and dropouts, victims of a system exploiting resources and causing an unequal distribution of material wealth.

People and organizations with a lot of Communitysense try to explore the inner beings of themselves or others. They refresh spirituality and seek to bring New Harmony. Generally Community is anti-dogmatic, and since everyone is unique, anti-labeling and anti-hierarchy, but highly tolerant.

Organizational features associated with Community

In Community, the process of organizing has become an end in itself. Not the organization as such matter that much, but a group of people engaged in a process of organizing. It implies the involvement of all others, within and outside the organization. Community values support competences enhancing the ability to involve everyone (engagement) and listen carefully (dialogue). In Community one tend to recognize the human being "behind" the employee and the customer. As Peter Drucker already noticed in 1952 "when hiring a worker, one gets a whole man": along with the muscles and brainpower comes the emotional and spiritual dimension. These capacities allow persons to better understand one other, to create a two-way flow of information, turning conversations into dialogues. Teamwork improves, as people are better able to work together.

Persons and organizations with a lot of Green are convinced that individual achievements alone are not sufficient to adequately confront the challenges Community Organizations are facing. In Community one believes that cooperation beats competition: "together we stand strong”. Fairness is a highly regarded value, both in the supply chain, especially when suppliers come from emerging economies, and in the pricing policy towards customers.

Success organizations mainly exploit their own resources and existing competences in trying to become better and better, while Community organizations learn to collaborate first internally and secondly by engaging with outside stakeholders. Examples for increasing internal coherence are quality orientations shifting from process to organization-wide, a people-driven philosophy and significantly improving workplace culture and practices. The newly acquired skills in dialogues and teamwork, support the engagement with outside stakeholders such 
as customers, suppliers, and neighborhood representatives. The engagement primarily commences as a consequence of corporate responsibility, expressing that the organization is accountable for its impact on others. By effectively working together with internal and external stakeholders, thus tapping into their competences and capacities, organizations find new opportunities to boost their performance. This time with respect to the triple bottom line: people, planet and profits.

The archetype leadership style in Community is "coaching"- the servant leader. The servant leader, a term coined by Robert Greenleaf, implies a state of being, not doing: the first and important choice a leader can make is the choice to serve, without which one's capacity to lead is profoundly limited [6]. Hierarchies are replaced by supportive structures. A typical expression is: "We take care of the people, the people take care of the business."

Instead of providing solutions, managers should allow the group to create the answers. With typical values such as consensus, conflict avoidance, teamwork, equality, participation, honesty, openness, being a decent person and harmony, decision making in the context of Community is an-often time consuming-group process. Once the decision is reached, the buy-in is guaranteed and implementation can be done quickly. This type of consensus-oriented decision-making implies that a new type of corporate governance structure has emerged, including a new role of management, a flat organization structure and shareholder value being balanced against the interest of other legitimate stakeholders.

In Community Organizations, the term Human Resources is no longer applicable to employees, and their satisfaction as indicator is surpassed by the level of trust which (ought to) exist between management and employees, between employees and among stakeholders such as customers, suppliers, shareholders and neighborurs. Human Talent Management is more appropriate, indicating its emphasis on the development of individual employees and the recognition of employees being assets

Order
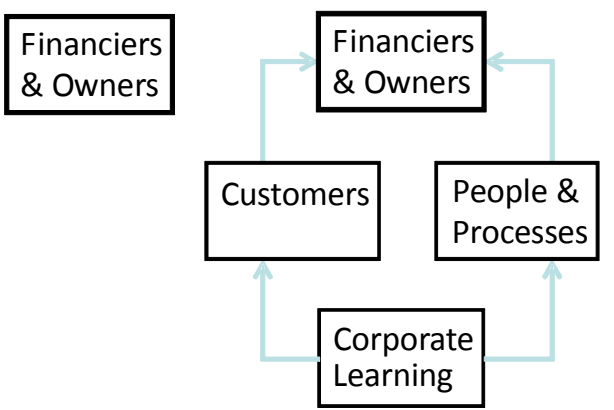

instead of costs.

The traditional focus on the material and commercial organizational competences are fading somewhat in favor for the socialization [7] among employees and other stakeholder groups: the ability to engage with people and uniting them in an attempt to achieve common goals. Previous organization types were resource oriented, but organizations applying engagement and collaboration as key concepts in Community strategies are stakeholder oriented. Stakeholders have become co-makers and cocreators. Strategic partnerships are common and institutional arrangements on sector level emerge.

The bulk of management tools supports Order and Success. Community related tooling is still rare. The ECSF project created an innovative measurement format: the Responsive Business Scorecard. This format includes four stakeholder groups, each with an interactive relationship with a fifth entity, the organizations itself. See Figure 1. The box in the middle-Corporate Performance Improvements - functions as an anchor point linking Community with Success, as much as Financiers and Owners linked the Balanced Business Scorecard with the Financial Report (Order).

The word "responsive" emphasize the Communion principle [8] and represents its willingness to interact with stakeholders and be accountable for their actions and impact to others. The Responsive Business Scorecard emphasizes the relationships with the main stakeholder groups and the extent to which these outcomes contribute to the improvement of the corporate goals.

The relationships with the stakeholders can be managed by applying the old Deming learning cycle Plan-DoCheck-Improve, or more appropriate to Community: Identify-Engage-Involve-Agree-Deliver-Learn and Improve.

Trying to be a decent person, nice and loving, is a highly regarded quality in Community. Conflict avoidance, how ever, also have negative consequences. With criticism smothered by love and judgments made relative to the

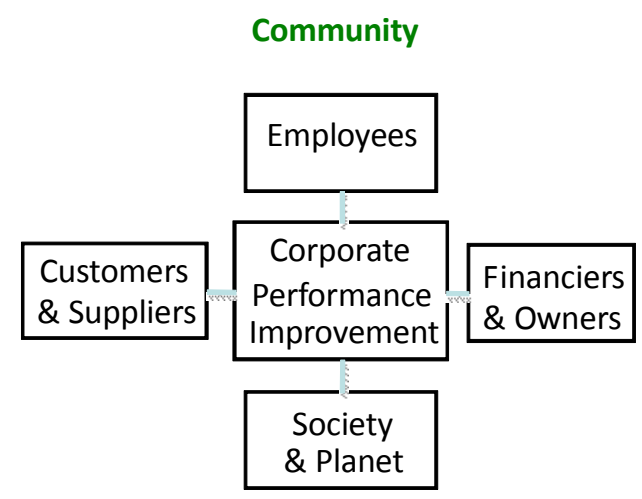

Financial Report Balanced Business Scorecard

Responsive Scorecard

Figure 1. Three manifestations of business reporting formats aligning specific development phases. 
situation at hand, decision-making risk non-functional and abstract outcomes.

Using each other's qualities for mutual growth, Community is able to create good learning conditions. However, the aura of an expert is badly regarded in Green: consensus is more important than expertise and incompetence is not a reason to be laid off. With rising complexity levels, Community does no longer provide the ultimate solutions to the problems at hand. Furthermore, equality and consensus building may lead to pooling of ignorance.

Being confronted by chaos in a world at-risk, typical Community features such as the lack of leadership and expertise and the emotional and economic cost of caring are important arguments to develop new ways to cope with more complex challenges.

\subsection{Synergy (the Integrating Self: Yellow)}

\section{Introduction of the Value System}

Comprehension, understanding and synergy are the buzzwords of Synergy. A person and organization with a lot of yellow, express itself, but never at the expense of others or the earth, so that all life may continue in the most natural, sustainable, and fitting ways. They recognize the inevitability of nature's flows. They understand that the complexity of today's world cannot be solved within the current systems, as their awareness of broad interconnections grows.

Synergy can find its way in a mix of conflicting "truths", for it is able to see more colors and uses more senses at the same time. By focusing on functionality and applying competencies to get buy - in from others, Synergy is able to create win-win options, seeking self-interest without doing harm to others and nature.

In discussing ideas, persons with a lot of yellow do not get personalized. They will not say: "These people can't cook", but "This food is not of good taste". Furthermore, in Yellow there is room for authenticy, since internal motivations matter a lot. Existentialism is strong.

Organizational features associated with Synergy

In order to meet its drive - to be, to learn and to discover-persons with a lot of Synergy function best in a network with a strong sense of direction: Yellow demands flexibility and open systems. Values such as insight, long-term orientation, ability to reflect and tolerance for uncertainty and paradoxes support the drive for self-development and boost people's ability to learn and apply knowledge. They are able to learn from any source. With a mind that quickly wanders, they have difficulty in maintaining focus.

Larger organizational entities transforming-or breaking up-into network structures, demonstrate the drive behind Synergy. The Hollywood movie scene is a good example of a once highly successful oligopoly, which broke up in numerous small professional clusters, who work together in a network for the duration of a project. Not far from Hollywood, in Silicon Valley, one can witnessed a network structure that emerged bottom up, independent professionals clustering into networks, creating the necessary competences to meet the challenges facing Synergy.

The archetype activity in Synergy is the "Emergence or connected Leader", who is both "visionary" and able to link the various qualities into one effective and coherent approach. The leadership style dominated by Synergy causes breakthroughs, supports transitions, directing its organisation into new innovative ways that alter business. Jim Collins' [9] “Good to Great”-concept of level five leadership fully coincides.

Real leadership is no longer confined to what people $d o$, but grounded in who people are. An authentic choice to serve life increases ones capacity to lead by allowing life to unfold through you. The hierarchy between the leader and the led remains healthy: leadership is never dominating or abusing raw power. The leadership potential can be developed in everyone. It implies identifying the personal responsibility and the alignment between one's personality and ambitions with one's role within the network. Therefore, essentially, leadership is about learning how to shape the future [6].

The basic guiding principle between people and their organization is the alignment between collective and individuals needs and motives. Alignment also takes place between the various entities within the network, including the stakeholders. Corporate behavior associated with this context can be characterized as "motivational”. Managers support their employees, often professionals, in order to bring them into the flow, accomplishing both their own as well as their organization's objectives and creating a feeling of self-actualization.

Employees accept career advancements only when they feel they are competent and when it is a nice job. Typical negative manifestations of synergy-driven people and organizations are the lack of commitment to organization and colleagues. They might appear aloof and uninterested or operate as loners. When they do not get enough interesting work they will abandon their position. Furthermore they are intolerant to rigidity and demands open access to information.

\section{Final Remarks}

\subsection{Transition Matrix}

The institutional structures of each ideal type can be summarized and structured according the enablers of the Global Excellence Model, one of the fundaments of the Cubrix [4]. See Table 2, below.

In coherent ideal type institutional structures, one can distinguish the left quadrant dimensions, introduced by 
Ken Wilber [10,11], specifically the ideal type cultures and intentional values people apply while coping with the challenges the ideal type organization is facing. These two topics are summarized below (see Table 3 ).

The ideal type organizations, introduced in this paper, cannot be recognized as actual organizations. However, in studying or monitoring organization development one can distinguish various elements from these ideal types. It also supports the gap analyses between ambitions, actual behavior and policies and the structural elements of these types. When these are not coherent, one should transform towards, or adopt institutional elements from the types that align better with the intentions and chal- lenges organizations are facing.

In practices, several challenges remain intact and groups of people often have a mix of values from various value systems, making it quite a challenge to determine which types of organization align best with the given goals. Vice versa, an actual set of institutions can jeopardize the ambitions when these ambitions cannot be met within the contemporary setting. Again, there are no simple cause relation effects in organization development.

This matrix can also be used as a framework for structuring, for instance, management literature, or all management tools, methods and theories, as these methods

Table 2. A developmental approach to corporate enablers, structured according to the GEM [4].

\begin{tabular}{|c|c|c|c|c|}
\hline $\begin{array}{l}\text { Development } \\
\text { Labels }\end{array}$ & $\begin{array}{l}\text { Compliance-driven } \\
\text { Order (Blue) }\end{array}$ & $\begin{array}{c}\text { Profit-driven } \\
\text { Success (Orange) }\end{array}$ & $\begin{array}{c}\text { Care-driven } \\
\text { Community (Green) }\end{array}$ & $\begin{array}{l}\text { Systemic-driven } \\
\text { Synergy (Yellow) }\end{array}$ \\
\hline 1. Leadership & Manager & Entrepreneur & Servant Leader & Emergent Leader \\
\hline 2. Strategy & Mergers \& acquisitions & $\begin{array}{l}\text { Autonomous growth due to } \\
\text { competitive qualities }\end{array}$ & $\begin{array}{l}\text { Stakeholder engagement; } \\
\text { Chain related }\end{array}$ & $\begin{array}{l}\text { Industry related, seeking } \\
\text { breakthroughs }\end{array}$ \\
\hline $\begin{array}{l}\text { 3. People } \\
\text { Management }\end{array}$ & $\begin{array}{l}\text { Personnel \& } \\
\text { Administration }\end{array}$ & $\begin{array}{l}\text { Human Resources } \\
\text { Management }\end{array}$ & Human Talent Management & Human Capital Management \\
\hline $\begin{array}{l}\text { 4. Communication } \\
\text { \& Decision } \\
\text { Making }\end{array}$ & $\begin{array}{l}\text { Top down, while applying } \\
\text { the procedures from higher } \\
\text { authorities }\end{array}$ & $\begin{array}{l}\text { Top down, but valuable info } \\
\text { from the bottom is always } \\
\text { welcome }\end{array}$ & $\begin{array}{l}\text { Bottom-up; group decides } \\
\text { based on consensus; } \\
\text { sociocratic }\end{array}$ & $\begin{array}{l}\text { Consent principle decides } \\
\text { who should make the } \\
\text { decision, as understanding } \\
\text { of the matter prevails }\end{array}$ \\
\hline $\begin{array}{l}\text { 5. Learning \& } \\
\text { Innovation }\end{array}$ & $\begin{array}{l}\text { Product innovation } \\
\text { based on technical } \\
\text { expertise }\end{array}$ & $\begin{array}{l}\text { Process innovation, and } \\
\text { product diversification }\end{array}$ & $\begin{array}{l}\text { Social Innovations, } \\
\text { developing supportive } \\
\text { structures to boost } \\
\text { learning and innovation }\end{array}$ & $\begin{array}{l}\text { System innovations, } \\
\text { based on in-depth } \\
\text { understanding of } \\
\text { dynamics, sustain-ability, } \\
\text { and needs }\end{array}$ \\
\hline 6. Resources & Price competition & $\begin{array}{l}\text { Maintenance on process } \\
\text { indicators }\end{array}$ & $\begin{array}{l}\text { Outsourcing with strong } \\
\text { relationships, peer audits }\end{array}$ & $\begin{array}{l}\text { Co-creating; together- win; } \\
\text { Sustainable Purchasing }\end{array}$ \\
\hline 7. Processes & Activity Orientation & Process Orientation & (Internal) System Orientation & Chain Orientation \\
\hline
\end{tabular}

Table 3. A developmental approach to corporate enablers-context related (GEM).

\begin{tabular}{|c|c|c|c|c|}
\hline $\begin{array}{l}\text { Development } \\
\text { Labels }\end{array}$ & $\begin{array}{l}\text { Order } \\
\text { (Blue) }\end{array}$ & $\begin{array}{l}\text { Success } \\
\text { (Orange) }\end{array}$ & $\begin{array}{l}\text { Community } \\
\text { (Green) }\end{array}$ & $\begin{array}{l}\text { Systemic-driven Synergy } \\
\text { (Yellow) }\end{array}$ \\
\hline 1. Culture & $\begin{array}{l}\text { Bureaucratic; procedural; } \\
\text { compliance-driven }\end{array}$ & $\begin{array}{l}\text { Entrepreneurial, } \\
\text { calculative; profit-driven }\end{array}$ & $\begin{array}{l}\text { Retiree Consensus; Em- } \\
\text { pathetic; care-driven }\end{array}$ & $\begin{array}{l}\text { Open, flexible, transparent; network } \\
\text { oriented; Systemic-driven }\end{array}$ \\
\hline
\end{tabular}


often align with specific contexts only. It is as if one simply opens up a specific drawer, from a wide chest of drawers, finding a full set of business institutions, management tools and concepts, whatever. Although it is a complicated framework, users only need to know the relevant aspects, the aspects related to their context only. By determining $\mathrm{A}$ and $\mathrm{B}$, referring to an initial context and situation and a desired state, the user will get a fullmanagement reference, indicating the various steps and sets of relevant information that will help getting them to the espoused situation. The framework can be used as an expert system, raising the right questions as well as providing the best answers.

A foundation has started - Stichting Koploperz (Leading Organizations Foundation) that will benchmark the best practices, structured according this framework.

In practice, some drawers are still empty, others are not fully filled and lacking coherence. So there is still a lot of work to do. However, we did analyze over 100 management tools, according their characteristics related to this framework, coined the Cubrix. In the near future we will create an online expert system. If you want to be involved, someway, let us know!

\section{References}

[1] M. van Marrewijk, "A Value Based Approach to Organisation Types: Towards a Coherent Set of Stakeholder

\section{Abreviations}

CEO Chief Executive Officer

CS Corporate Sustainability

CSR Corporate Social Responsibility
Oriented Management Tools,” Journal of Business Ethics, Vol. 55, No. 2, December 2004, pp. 147-158.

[2] D. Beck and C. Cowan, "Managing Values, Leadership, and Change," Spiral Dynamics, Blackwell Publishers, London, 1996.

[3] M. van Marrewijk and M. Werre, "Multiple Levels of Corporate Sustainability," Journal of Business Ethics, Vol. 44, No. 2-3, May 2003, pp. 107-119.

[4] M. van Marrewijk, "The Cubrix, an Integral Framework for Managing Performance Improvement and Organisational Development," Journal of Technology and Investment, Vol. 1, No. 1, 2010, pp. 1-13.

[5] J. W. Newstrom and K. Davis, "Organizational Behavior,” 10th Edition, Mc. Graw-Hill, New York, 1997.

[6] J. Jaworski, "Synchronicity: The Inner Path of Leadership,” Indigo, 2000.

[7] T. W. Hardjono, "Ritmiek en Organisatiedynamiek: Vierfasenmodel,” Kluwer, 1995.

[8] M. van Marrewijk, "Concepts and Definitions of Corporate Sustainability,” Journal of Business Ethics, Vol. 44, No. 2-3, May 2003, pp. 95-105.

[9] J. C. Collins, “Good to Great,” Harper Collins Publishers, New York, 2001.

[10] K. Wilber, "Sex, Ecology, Spirituality: The Spirit of Evolution,” 2nd Shambhala Publications, Boston, 1995.

[11] K. Wilber, "A Theory of Everything: An Integral Vision for Business,” Politics, Science and Spirituality, Shambhala Publications, Boston, 2000.

ECSF European Corporate Sustainability Framework

ECLET Emerging Cyclical Levels of Existence Theory

GEM Global Excellence Model

LC Life Conditions

MC Mind Capacity 